\title{
Chapter 6 \\ The Measurement of Social Stratification: Comparative Perspectives Between Europe and Latin America
}

\author{
Emmanuelle Barozet, Marcelo Boado, and Ildefonso Marqués-Perales
}

\begin{abstract}
This chapter analyses compared social stratification in three Latin American countries (Argentina, Chile and Uruguay) and four European countries (Finland, France, Spain, Great Britain). We focus on both external and internal borders of social classes, as well as on the challenges posed by their analysis for sociology. We compare social classes using EGP6 in relation to a variety of social indicators, to examine how social classes vary among countries. We include debates on production models and welfare state policies to understand the specific configurations and compare the conditions of some of the INCASI countries regarding social stratification. Lastly, we apply a latent class analysis to validate the number of social classes and to recognise class boundaries.
\end{abstract}

\subsection{Introduction}

In a scenario characterised by global and accelerated social change, the comparative study of social structures and classes may be considered a major current sociological challenge. New forms of social organisation coexist with old ones, blurring the strata that shape our societies. Nevertheless, because of the rise of inequalities on a global level since the 1980s, there is no doubt that social classes and social stratification have experienced a revival in sociological research. Several areas

\footnotetext{
E. Barozet $(\bowtie)$

Centro de Estudios de Conflicto y Cohesión Social, Universidad de Chile, Santiago, Chile e-mail: ebarozet@uchile.cl

M. Boado

Grupo de Investigación en Estructura, Movilidad y Capital Social, y Desigualdades Educativas (GEMCED), Departamento de Sociología, Universidad de la República, Montevideo, Uruguay

e-mail: marcelo.boado@cienciassociales.edu.uy

I. Marqués-Perales

Departamento de Sociología, Universidad de Sevilla, Sevilla, Spain

e-mail: imarques@us.es 
such as political sociology, social mobility and epidemiology have reinvested in this concept in order to give a better account of wider social disparities, while other forms of social organisation defy current social class approaches. This chapter compares the social structure of three Latin American (Argentina, Chile and Uruguay), and four European countries (France, Great Britain, Finland, Spain). This selection responds to the fact that they are INCASI countries with enough data available to develop our objectives. They also cover comparatively different types of social models.

To date, there no available comparative analysis of social classes among the selected countries, following objectives and methods as we do here. For instance, the International Social Survey Programme ${ }^{1}$ has partially included Latin American nations and the World Values Survey, ${ }^{2}$ but does not allow the use of international current stratification schemes. Therefore, the general aim of this work is to compare the social structures of both regions, based on the degree of possible convergence between a set of seven countries. By convergence we are referring to the fact that the social classes have to be similar not only in number, order and proportion. In other words, regardless of the living conditions each social class may have, it means that these are similar in each country; they also have the same magnitude and hierarchy. In international literature on social stratification, there is a certain consensus when admitting that all class positions are organised in the same way, regardless of the society in question. We examine to what degree this statement proves to be true. The invariance of social structures (Inkeles and Rossi 1956) is currently known as the Treiman Constant (Treiman 1970, 1975, 1977; Hout and Di Prete 2006) after the North American sociologist who was the first to formulate it systematically.

Our hypotheses are based on the referenced international bibliography. On the one hand, the reliability and support of convergence in social inequality on a global level is expressed. On the other hand, the determination of the economic dimension is opposed to the intervention of welfare policies, which define the subsets of countries. Therefore, the following hypotheses are expressed:

H1 Social classes present a high level of similarity in their social structures in all the countries analysed.

Social classes are organised in similar proportions and a similar order in the selected countries. We start from the Treiman Constant which maintains that the way in which class positions are organised is similar in all countries and that, moreover, income, quality of the jobs and living conditions will follow a similar order to that set out by EGP in their version of six classes, following its vertical dimension.

H2 The economic bases of social classes are disparate depending on whether we analyse Europe or Latin America.

Although we have indicated that the order in which the classes are grouped is similar, we postulate that the economic bases sustaining them are different in

\footnotetext{
${ }^{1}$ http://w.issp.org/menu-top/home/

${ }^{2}$ http://www.worldvaluessurvey.org/wvs.jsp
} 
composition. In other words, as we move from the wealthier countries toward the less wealthy countries, from Europe to Latin America, the welfare level encompasses a lower number of social classes, and, as a result, access to welfare is more unequal. Thus, in Latin American countries, welfare is of a more heterogeneous nature than in Europe. It only reaches those situated in the intermediate classes [small proprietors (IVab) and routine non-manual class (IIIab)] and the service class [managers and professionals I + II)]. As stated by Filgueira and Geneletti (1981), these historical processes and social classes are the result of a heterogeneous capitalism and a selective spread of modernisation.

Regarding the structure of this chapter, first, we present descriptive differences between the two continental subsets (Latin American and European), regarding their social class structure, applying the EGP scheme-using only six categories (hereinafter EGP6). We also include their recent regional and national history, using the literature about varieties of capitalism (Hall and Soskice 2001). Second, we focus our theoretical-methodological reflection on social stratification in a comparative frame, in relation with current debates. Third, we set out the model of our comparative analysis between the selected INCASI countries. Fourth, we assess and contrast the differences between Latin American and European countries. This analysis facilitates a better comprehension of the composition of classes measured through the EGP scheme. We use socioeconomic variables to characterise these classes in the selected countries regarding welfare state policies. We then validate the internal consistency of social classes in a comparative perspective based on a latent class analysis in relation to their productive and welfare systems.

\subsection{Comparative and Historical Overviews}

In this first section, we present key elements of comparison between INCASI countries (Marqués Perales and Chávez Molina 2019), to provide context. We pay attention to disparities between Europe and Latin America, following the literature related to the timing of industrialisation and the frame developed by INCASI in the previous chapters. Gerschenkron (1962) pointed out that late-modernisation processes generated substantial benefits. This means that several countries shortened the industrialisation period by saving innovation costs, which have already been borne by the early-industrialised countries (Ishida 2008). Nevertheless, early industrialised countries have fewer horizontal social class differences than Southern European and Latin American countries, due to the greater presence of more competitive and rational markets.

Referring to the literature on the variety of capitalism (Hall and Soskice 2001), we also present key elements of comparison among the countries included in the INCASI project. In this regard, Maloutas (2009) has pointed out that in Southern European societies, the marginalisation of occupational status affects class attribution. While this is true for Southern European countries, it is even more appropriate regarding Latin American social structures in which the informal labour sector is larger. We also introduce elements such as sex as a variable and gender 
relations as a context, ${ }^{3}$ because they shape economic processes and social stratification differentially in Latin America and Europe.

In general, both regions are free market economies, with democratic governments, centralised educational systems-except Chile-and nuclear family structures. However, the level of efficiency and inclusion of the markets is different, as is the performance of their governments regarding the function of schools and the role played by families. Economic historians have considered that one of the main differences between both continents stems from the different positions they occupy on the world economic board (Prebisch 1949; Cardoso and Faletto 1969; Wallerstein 1974, 2000; Inglehart and Baker 2000). European countries are part of the economic core in which the most lucrative activities of the global market are generated (Maddison 2006). Europe as a whole underwent very early industrialisation, education and secularisation processes which reached the majority of its towns in different degrees, except Spain and Finland, which joined this process more recently and at a more accelerated pace (Barro and Lee 2013; World Bank 2015). In Latin America, these processes occurred later, and the industrialisation was different, particularly in the smaller countries, which did not have a sufficient internal market in terms of demand or did not have an economy integrated with their neighbours. In the past 50 years, economic globalisation processes were of a peripheral nature and in Latin America they had different consequences. The theory of structural heterogeneity underscores the coexistence of two differentiated sectors in Latin American countries: a first sector in which labour productivity is high, similar to that attained by the economies of the core countries, and another sector in which the productivity is much lower compared to that recorded in core economies (Pinto 1969; Chena 2009; Solís et al. 2019).

As indicated in Chap. 2, since the economic downturn in 2008 in Europe, income inequality increased, while in Latin America, on the contrary, there was an expansive economic period based on the mass exportation of commodities, which reduced income inequality. The evolution of the Gini index points to a stable social expenditure or a slight increase in European countries, for example, in France, Finland and Spain, and a slight decrease in Great Britain. Meanwhile, in the Latin American countries, the increasing effect of the expansive economic cycle reduced the gap between both Gini, with slight increases in all cases. To conclude, the cyclicalgrowth — and anticyclical-welfare regime — effects faced by each subset of countries can be observed at the same time.

\footnotetext{
${ }^{3}$ We do not include ethnic or racial data in this chapter because not all databases collect this information. Nonetheless, we point out that this is a crucial variable to describe social structures more accurately and explain the internal composition of social classes in most countries. Regarding the frontiers dividing social classes, in addition to traditional vertical differences, the inclusion of more variables (specifically age, territories, place of residence and identities) has given rise to a greater concern for the measurement of horizontal ones, but this goes beyond the scope of this chapter, though we are aware of the importance of these dimensions.
} 
Table 6.1 Typology of social models

\begin{tabular}{l|l}
\hline Social model & Countries \\
\hline Neo-corporatist coordinated economies & Finland \\
\hline Semi-coordinated mixed economies & Spain, France \\
\hline Uncoordinated economies & Great Britain, Chile \\
\hline Uncoordinated informal economies & Argentina, Uruguay \\
\hline
\end{tabular}

Source: Chap. 2

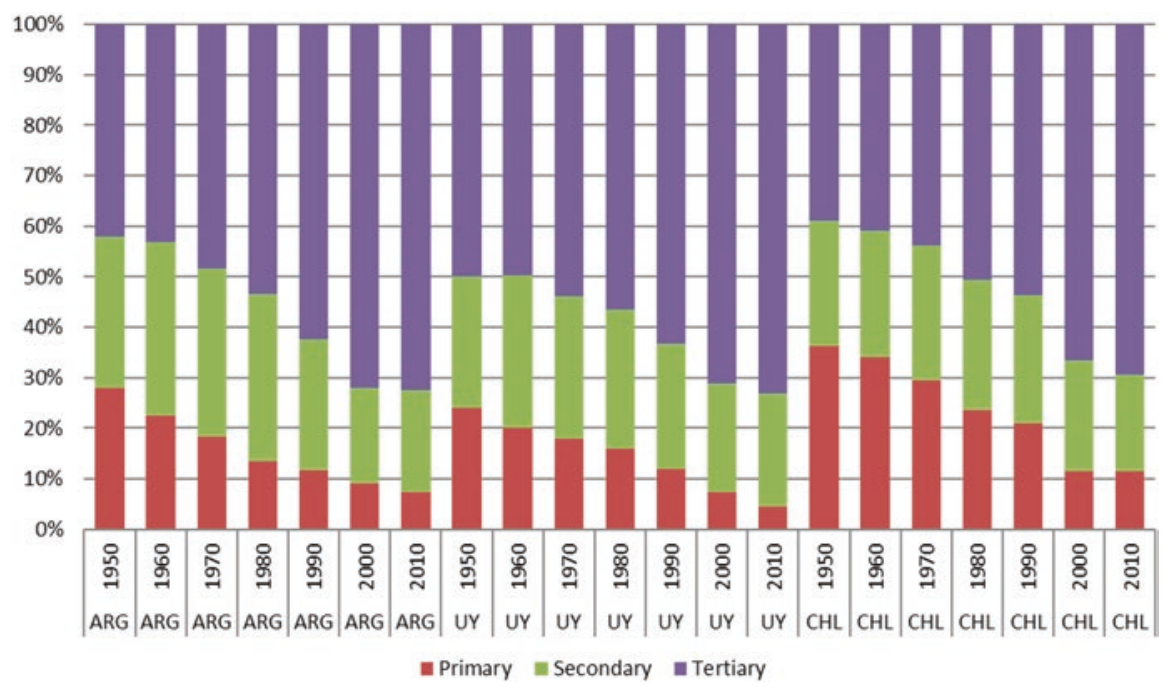

Fig. 6.1 Sectorial distribution of the EAP of both sexes, selection of INCASI Latin American countries, 1950-2010. Source: Maddison Project

Regarding social models, and using the typology presented in Chap. 2, our two subsets of countries include four of the six types elaborated (Table 6.1): ${ }^{4}$

In order to emphasise the several factors of the stratification process, we now present the historical sectorial distribution ${ }^{5}$ of the economically active population (hereinafter EAP) using the Maddison project data from 1950 on (Maddison 2006 version Bolt et al. 2018) for the nations studied here.

The three Latin American countries (Fig. 6.1) show a similar pattern of continuous decline both of the primary (decreasing from $25 \%$ to $10 \%$ of EAP) and secondary sectors (decreasing from $32 \%$ to $20 \%$ of the EAP). Chile had the largest rural sector in the 1950s and today Uruguay presents the smallest primary sector, lower than $10 \%$. These countries also have a higher and earlier tertiary sector. In Uruguay,

\footnotetext{
${ }^{4}$ For a detailed description of each model, see Chap. 2. There are differences within these geographical areas. The nature of the institutions is also very different in these territories, but in this chapter, we focus on the comparison.

${ }^{5}$ The three sectors are primary (agriculture and extractions), secondary (manufacturing, power and construction) and tertiary (trade, communications, finance, health, education and services).
} 


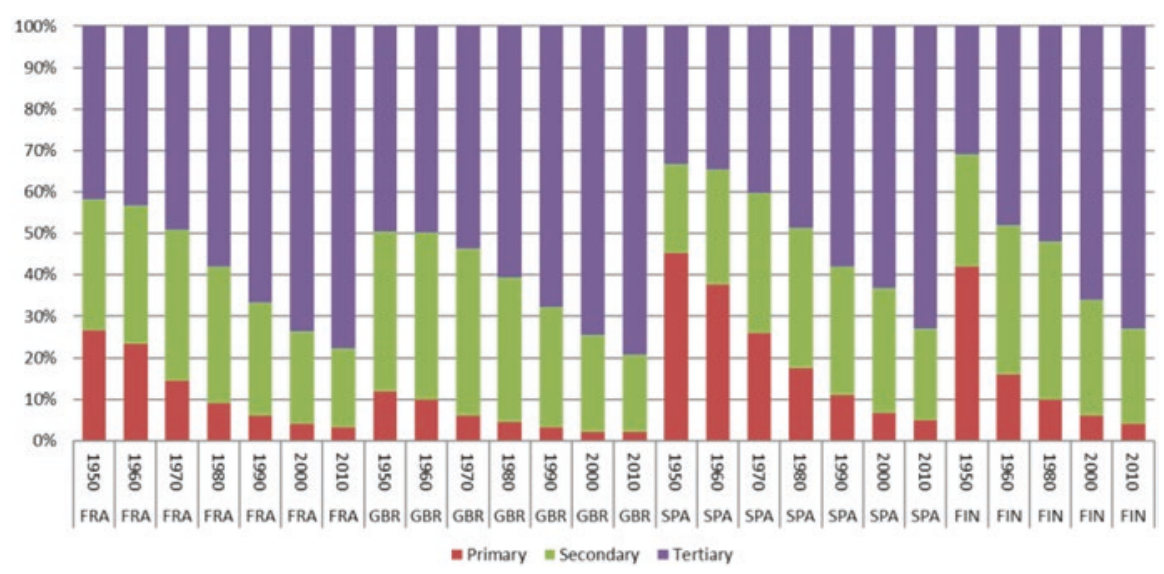

Fig. 6.2 Sectorial distribution of the EAP of both sexes, selection of INCASI European countries, 1950-2010. Source: Maddison Project

this sector has increased from $50 \%$ of the EAP in the 1950 s to $70 \%$ today. Argentina and Chile almost doubled their EAP in the tertiary sector between 1950 and 2010.

All European countries (Fig. 6.2) in the chart above illustrate the almost disapearance of the primary sector, and a larger and resilient secondary sector than in Latin America. From around 30\% to almost $80 \%$ in some cases, the tertiary sector has shown a steady upward trend, sometimes faster than in Latin American countries.

Although many differences separate Europe from Latin America, both regions are influenced by similar economic and social forces. Despite having diverse historical backgrounds, the forces driving globalisation -liberalisation of international trade, the quest for technological innovation, the increase in financial capital (Friedman 1999; Castells 1996) — have had a strong impact on both sides of the Atlantic.

\subsection{A Theoretical-Methodological Framework for Comparative Social Stratification}

In this section, we briefly examine the tools available and the reasons why we chose EGP, as social categories and their measurement are still largely debated nowadays. Specifically, there is a dispute in comparative studies between sociology's definitions and instruments (Grusky 2001) on the one hand, and economics and international institutions focused on the analysis of growth and consumption on the other (World Bank 2015).

We already know how several useful tools (median income, occupational groups, income or consumption segments PPP, EGP, Erik Olin Wright scheme, Treiman status scores, IPICS, among others), show social spaces that vary according to the region and the variables used. Alternative measures for Europe are the Industrial 
Table 6.2 EGP6 social classes

\begin{tabular}{|c|c|}
\hline Classes & Description \\
\hline $\mathrm{I}+\mathrm{II}$ & $\begin{array}{l}\text { Service class: professionals, administrator and managers, higher-grade, supervisors } \\
\text { of non-manual workers }\end{array}$ \\
\hline IIIab & $\begin{array}{l}\text { Routine non-manual workers: routine non-manual employees in administration and } \\
\text { commerce, sales personnel, other rank-and-file service workers }\end{array}$ \\
\hline IVab & Petty bourgeoisie: small proprietors and artisans, etc., with and without employees \\
\hline $\mathrm{V}+\mathrm{VI}$ & $\begin{array}{l}\text { Skilled workers: lower-grade technicians, supervisors of manual workers, skilled } \\
\text { manual workers }\end{array}$ \\
\hline VIIa & Non-skilled workers: semi- and unskilled manual workers (not in agriculture. Etc.) \\
\hline $\mathrm{IV} c+\mathrm{VIIb}$ & $\begin{array}{l}\text { Farmers and agricultural laborers: farmers and smallholders and other self- } \\
\text { employed in primary production, agricultural and other workers in primary } \\
\text { production }\end{array}$ \\
\hline
\end{tabular}

Source: Erikson and Goldthorpe (1992)

Post-Industrial Social Class (IPICS; Hertel 2017) and the European Socio-economic Classification (ESeC) (Rose and Harrison 2007; Penissat and Siblot 2017). In Latin America, on a comparative basis, we can underline Torrado's class scheme (1998), as well as that proposed by Portes and Hoffman (2003), but they do not facilitate an international and intercontinental comparison. Erikson, Goldthorpe and Portocarero's (EGP) scheme (1992) is widely preferred in Europe, but less so in Latin America. Its application is more flexible and affordable for comparison though than Wright's exploitation typology (1997). Recently, Solis and Boado (2016) pointed out that the use of the EGP scheme has been crucial to add the Latin American case to the international academic debate on social stratification and intergenerational class mobility. In this document we follow the version of EGP categories that the authors compiled in a comparative perspective. They first built an eleven-class scheme and divided it into seven categories. We did the same, but because of sample sizes, we chose to divide the scheme into six categories, EGP6.

In Table 6.2, the social classes appear with a brief description of the groups comprising them.

However, such advances in comparability came at a high price because data was produced by academic teams with no special coordination unit at the time of the application of the national surveys. In Latin America, since there is no organisation generating comparable data-the Economic Commission for Latin America (ECLAC) of the United Nations only collects data produced by the states-, the efforts depend on national teams, often universities.

The work carried out by our teams in Latin America considers two waves. First, from 2009 to 2014, in each country, one of the first initiatives is a wave of surveys undertaken by our teams in Argentina, Chile, and Uruguay in the 2000s, ${ }^{6}$ which were later grouped together and compared. In a second phase (2014-2019), we extended the comparison to Western Europe through the coordination of the INCASI

\footnotetext{
${ }^{6}$ Mexico and Brazil are also represented in this first comparison, but we will focus on the countries studied here.
} 
project. Notable progress has been made towards a common nomenclature in the case of Europe, compared to some dispersion and laborious coordination of the data in the case of Latin America, including a lack of data for some countries. As each nation in Latin America uses different currencies and there are no conversion tables between scholar systems, the statistical work behind our results is more time consuming than with European data. The main characteristics of the surveys used in this chapter are detailed in the Appendix. Data includes individuals who are over 25 years old and under 65 years old.

The goals we set ourselves will be tackled below in two ways. The first part of this research is of a descriptive and informative nature. The purpose of the second part is to contrast and validate. To give an account of the differences in the class divisions between men and women, we will analyse the subsamples of each country separately, since gender relations afford a specific profile to the class structures of men and women (Crompton and Mann 1986).

\subsection{Class Structure by Sex in European and Latin American INCASI Countries}

In this section, we will compare the social class structure of both subsets of countries. Table 6.3 shows the percentages of men per social class in all the countries selected.

The main difference between the class structure of European and Latin American countries lies in the low proportion of the service class (I + II) in general, and in particular in Latin American men compared to Europeans. While this category in Latin American countries does not quite reach one out of four members as managers and professionals, in European countries it exceeds three out of ten. The administrative, customer service and routine non-manual (IIIab) classes are reduced in both sets of countries, especially among Finnish men. The petite bourgeoisie (IVab) is reduced among European men, except in Spain. In Latin American countries, it is a more frequent class, exceeding the proportion of Spaniards. It is important to consider that there is certain heterogeneity in the composition of this category which includes from small employers to independent artisans. Skilled male manual workers are always the third largest class in all the European countries, and in Chile,

Table 6.3 Percentage of social classes according to EGP6 scheme for male population

\begin{tabular}{l|c|c|c|c|l|l|l}
\hline Men & France & Great Britain & Spain & Finland & Argentina & Uruguay & Chile \\
\hline I + II & 37.35 & 36.61 & 21.99 & 39.04 & 17.5 & 13.9 & 20.9 \\
\hline IIIab & 9.44 & 6.66 & 8.43 & 2.95 & 10.6 & 15.3 & 11.1 \\
\hline IVab & 7.35 & 9.57 & 12.55 & 7.88 & 15.3 & 9.4 & 16.7 \\
\hline V + VI & 17.94 & 11.19 & 16.36 & 18.59 & 23.2 & 23.5 & 16.4 \\
\hline VIIa & 24.44 & 33.38 & 33.98 & 24.62 & 27.8 & 27.6 & 21.7 \\
\hline IVc + VIIb & 3.48 & 2.59 & 6.68 & 6.92 & 5.5 & 10.3 & 13.2 \\
\hline
\end{tabular}

Source: ESS-4 and 5, ENES (Argentina), ENES (Chile), ELPS 
Table 6.4 Percentage of social classes according to EGP6 scheme for female population

\begin{tabular}{l|l|l|c|c|l|l|c}
\hline Men & France & Great Britain & Spain & Finland & Argentina & Uruguay & Chile \\
\hline I + II & 34.7 & 27.88 & 18.46 & 33.2 & 27.3 & 22.1 & 18.9 \\
\hline IIIab & 23.29 & 26.25 & 20.01 & 16.18 & 20.0 & 25.0 & 26.9 \\
\hline IVab & 17.14 & 26.04 & 25.22 & 25.21 & 15.0 & 16.4 & 10.0 \\
\hline V + VI & 2.6 & 2.1 & 5.42 & 2.4 & 7.2 & 5.4 & 9.2 \\
\hline VIIa & 20.01 & 17.52 & 27.36 & 19.1 & 29.8 & 26.7 & 32.4 \\
\hline IVc + VIIb & 2.25 & 0.21 & 3.55 & 3.9 & 0.6 & 4.4 & 2.6 \\
\hline
\end{tabular}

Source: ESS-4 and 5, ENES (Argentina), ENES (Chile), ELPS

while it is the second in size in Argentina and Uruguay. The class of unskilled male manual workers (VIIa) has a common feature in both sets of countries and its general size is always notable. It is the largest category in Spain, Argentina, Chile and Uruguay, while it is the second in Great Britain, France and Finland. The size of the rural classes (IVc + VIIb), which at present includes small landowners and day labourers, is largest in Chile and Uruguay, coinciding with the abovementioned deruralisation of European countries and Argentina.

Table 6.4 shows the percentages of women per social class in the same countries.

The first notable datum for women is that the size of the service class (I + II) in France, Great Britain and Finland is bigger than in Spain and most of the Latin American countries, apart from Argentina. But the sizes of this category in the Latin American countries have fewer gaps with the European ones; and these gaps, which are fewer than in the case of men, show that, despite the smaller size of the service class, there is no restricted access to women in the Latin American countries. In fact, Argentina, Uruguay and Chile exceed Spain. The second fact that stands out in the female structure is the large proportion represented by the administrative, customer service and routine non-manual (IIIab) class. In all the countries, this class is twice the size of the male equivalent in the corresponding countries. If it is combined with the service class, in all countries, apart from Spain, it exceeds $45 \%$ of the total class positions, which points to a tendency to polarise the female structure. The third aspect, in the vein of what we have just mentioned, is the size of the unskilled manual class (VIIa) in women. Spain has the largest proportion of unskilled manual workers out of the European countries. To be even more precise, it is the most numerous class for woman in Spain, Argentina, Chile and Uruguay, while it is the fourth in the order of proportions among the other European countries. A fourth aspect points to the common trait in both continents: the low presence of women in the skilled manual work class $(\mathrm{V}+\mathrm{VI})$, although in the Latin American countries the participation is slightly higher than in the European ones. Mobility studies indicate that this is one of the posts that is least reproduced among women in any type of country, as it is a predominantly a male position. In fifth place, the class referring to the petite bourgeoisie (IVab) is the second position in size in Spain, and the third in France, Great Britain and Finland; while it is the fourth position in size among the female population from the countries in Latin America. Lastly, the presence of women in the category uniting the rural classes (IVc $+\mathrm{VIIb}$ ) does not show an 
important proportional presence in general in all the countries. However, when the data is linked to the proportion of the similar category in the distribution among men, it is observed that this class does not appear to be preferential for women.

In general, we can summarise the information with the following ideas. First, the main differences between both continents can be observed in the proportion of the service class (I + II); this was also noticed by Solis and Boado (2016) in other data. It is not surprising to observe the greater vigour of the European economies and the presence of the State as a generator of skilled employment, which justifies the greater proportion of managers and professionals of all types. This trend in the European countries is stronger in the male social structure than in the female one. In turn, in the Latin American countries, class I + II are more prevalent, and the opposite occurs in terms of sex, with a wide female prevalence in all countries. Second, in general it can be observed that Spain is the European country that is most similar to the Latin American countries selected. Third, in both continents, the female social structure is polarised, with $45-60 \%$ tending to be concentrated in a vast non-manual sector and the skilled manual sector is reduced. This trend converges with that of men in Europe, but it is not similar to men in Latin America. In fourth place, the activity of small businesses representing class IVab is greater in Europe than in Latin America; and it is of more importance especially for women from both continents than for men. In fifth place, skilled manual work $(\mathrm{V}+\mathrm{VI})$ is predominantly male in Europe and in Latin American countries. Lastly, despite all the sectorial policies in the European Union, the rural classes are consistently decreasing with people leaving for urban jobs. Only in those Latin American countries where the weight of the exportation of commodities is very significant, despite the lack of agricultural protection policies, a productive and modernised agricultural sector is maintained; this points to the reversion of internal countryside to city migration in Chile and Uruguay, as well as the higher presence of men than women among the small landowners and workers. This aspect, in general, was clear when we observed the secular transformation processes of the EAPs occupied in the selected countries: the de-ruralisation was more severe in Europe than in Latin America, as was the resistance in the industrial sector.

With a view to verifying to what extent the social structures of the selected countries are similar, we have compiled a matrix of nominal contrasts with the statistic chi-square $\left(\chi^{2}\right)$, as can be observed in Table $6.5 .^{7}$

As regards men, Spain does not have statistically significant differences in the proportions of its class structure compared to Argentina, Uruguay and Chile, or Great Britain out of the European countries. There are differences of between 0.06

\footnotetext{
${ }^{7}$ We set four levels to accept the convergence hypothesis: 0.001 , a very low probability value, indicates that $\chi 2$ has a very large discrepancy from the expected value; from 0.01 to 0.05 , indicates a significant difference, in other words, that $\chi 2$ is less than in the previous case; from 0.06 to 0.10 , a less conservative interval, and indicative of a lower $\chi^{2}$ value than the previous one, but as a result of randomness in the samples it could indicate a possible difference; and lastly, we categorise with a "No" all the results of contrasts with a very small $\chi^{2}$ and $p$ values that exceed 0.101 and go up to 1 .
} 
Table 6.5 Contrast matrix $\chi^{2}$ among the social structures of selected countries

\begin{tabular}{|c|c|c|c|c|c|c|c|}
\hline & SPA & FRA & GRB & FIN & ARG & CHL & URY \\
\hline \multicolumn{8}{|l|}{ Men } \\
\hline SPA & 1 & & - & - & - & - & - \\
\hline FRA & $*$ & 1 & - & - & - & - & - \\
\hline GRB & No & No & 1 & - & - & - & - \\
\hline FIN & $*$ & No & ** & 1 & - & - & - \\
\hline ARG & No & $* *$ & $* *$ & $* *$ & 1 & - & - \\
\hline CHL & No & $* * *$ & $* * *$ & $*$ & No & 1 & - \\
\hline URY & No & $* * *$ & $* * *$ & $* *$ & No & No & 1 \\
\hline \multicolumn{8}{|c|}{ Women } \\
\hline SPA & 1 & & - & - & - & - & - \\
\hline FRA & No & 1 & - & - & - & - & - \\
\hline GRB & $*$ & No & 1 & - & - & - & - \\
\hline FIN & No & No & No & 1 & - & - & - \\
\hline ARG & No & No & ** & $*$ & 1 & - & - \\
\hline CHL & $*$ & $* *$ & *** & $* * *$ & No & 1 & - \\
\hline URY & $*$ & $* * *$ & $* * *$ & $* * *$ & No & No & 1 \\
\hline
\end{tabular}

Source: ESS-4 and 5, ENES (Argentina), ENES (Chile), ELPS. *** 0.00; ** 0.01-0.05*0.06-0.10

and 0.1 with France and Finland. Once again, it is corroborated that there is an intermediate position of class structure inequalities among the two subsets of countries. France does not present statistically significant differences in its classes compared to Great Britain and Finland. Compared to the three Latin American countries, the European nations - except Spain—do have notable and valid differences with $\mathrm{p}$ values less than or equal to 0.05 . The differences between Great Britain and Spain and France for men have already been mentioned; however, there is a significant difference with Finland. It is important to mention that, for men from Latin American countries, there are no statistically significant differences between their social class structures; they are quite similar despite the aspects mentioned at the beginning of this section.

The contrast for women is somewhat dissimilar. Spain does not present statistically significant differences in terms of social class structure compared to France and Finland in Europe, or with Argentina in Latin America. It also shows differences at the cusp of statistical significance with Great Britain, Uruguay and Chile. France does not have differences compared to Spain, Great Britain or Finland as regards female class structure, or with Argentina. On the contrary, there are significant differences, with $p$ values less than or equal to 0.05 , compared to Chile and Uruguay. Great Britain and Finland do not have significant differences between their female class structures, but they do with the three Latin American countries, although it can be observed that between Finland and Argentina there is not a very convincing difference.

In short, as regards the female class structure, the Latin American countries are not a block like in the male case, or like the European countries in general. 
Uruguay and Chile are clearly dissimilar for women compared to the sizes of the European classes and compared to Argentina. Thus, Argentina plays an intermediate role, like France, Spain and Finland in the female aspect of class structure, perhaps in a more evident way than Spain as an intermediate country in the male dimension.

As a first step towards the conclusions, we observe that the reach of the Treiman Constant indicated as a starting hypothesis is weak. The Latin American countries, in the context of men, are clearly separate from the European countries, even when Spain has an intermediate position, not very distant from the former, but similar to the latter. However, in the context of the comparison of the class structures protagonised by women, although the results do not contribute towards sustaining the Treiman hypothesis, the panorama is different: the European countries are further removed at the start and Argentina is similar to three of them, France, Spain and Finland, while it clearly differs from Chile and Uruguay.

\subsection{Compared Social Classes: Method and Contrast of Contents}

Now we will show that the presence of heterogeneous social protection regimes in both continents serves to enrich the debate on social structure, with several social groups being "mobile targets" for social stratification studies (Esping-Andersen 1990; Chauvel 2006), as shown by recent research in Europe and Latin America performed by the INCASI team. Esping-Andersen underlined the fact that standard social schemes have been devoid of institutional elements. He noted that orthodox class schemes are like overlapping "institutionally nude" worlds in a comparative perspective, though one might expect a greater degree of accuracy in their application to national contexts. The fact that standard classifications have been taken as a point of arrival rather than as a starting point has further fuelled this lack of institutional dimension (or of historicity). While it may be in accordance with the fact that individuals (employers and workers) by means of rational decisions form aggregates (classes), it is no less true that this balance can be modified by collective action and social policies. Also, state policies have an impact on social stratification as the result of a balance of power (Korpi 1983). With this in mind, we selected relevant variables to examine how the composition of social classes varies in each country (Table 6.6). Let us remember that, of the European countries, Finland is an

Table 6.6 Summary of variables selected by social class

\begin{tabular}{l|l}
\hline Variable & Categories \\
\hline Net family income & Deciles \\
\hline Seniority in employment & Continued years in the workplace \\
\hline Size of the company & Small, medium or large firm \\
\hline Public-private sector & Public-private \\
\hline Education in terms of knowledge and skills & Isced level 0 a 2; 3; 4; 5 and more \\
\hline Subjective perception of income & Person who claim to have economic problems \\
\hline
\end{tabular}


example of the Nordic universal welfare regimes. In other words, a sample of the group of countries with a neo-corporatist coordinated economy; Spain and France represent the Mediterranean regimes in Europe (Moreno 2006), with semicoordinated mixed economies and Great Britain represents the liberal model based on the market (Esping-Andersen 1990), in other words, a non-coordinated economy. In turn, Argentina and Uruguay correspond to the Latin American model, that is, non-coordinated informal economies, while Chile corresponds to the liberal model, like Great Britain, that is, a non-coordinated economy.

Below, we will cross social class with other variables that give an account of the economic and welfare conditions of these seven countries. We understand that the economic variables clearly indicate the associated life opportunities of each social class. Our work hypothesis is that these variables are distributed in the same order as the social classes from the EGP6 scheme. As we use individual variables and others that represent households, we use the head of the household as the social class referent.

First, to give an account of the economic capital of families, we work with deciles of net family income. Second, we analyse the differences in terms of seniority in employment, to determine to what extent social classes have constant and secure income. Third, we analyse the size of the company, because the size of companies is associated with productivity. In particular, it is appropriate to analyse to what extent the members of each social class work in large establishments. As regards the economic sector, the size of public employment must not be forgotten, because it grants better protection than private employment. Fourth, we consider education in terms of knowledge and skills. As a proxy variable we use educational level (ISCED), which is also a channel of social mobility in our societies. It helps to establish how human capital stock is distributed among the classes of a certain society. By including this variable, we consider education not only as an outcome variable of social class, but as a generating variable. Lastly, we add the subjective perception of income. With this variable, we seek to determine to what extent the abovementioned economic conditions unequally affect the position of individuals in the different social classes.

\subsubsection{Income}

With the graphs included in Fig. 6.3, we analyse the economic bases of social classes. For each country, the mean of the household net income decile is presented for each social class and according to sex, scaled in the mean of the deciles of the net household income distribution, regardless of the sex of the household head. The mean is incorporated as a reference.

First, in all the countries selected, the service class (I + II) is first, followed by the routine non-manual class (IIIab) in second place, the petite bourgeoisie (IVab) in third place, manual work $(\mathrm{V}+\mathrm{VI})$ in fourth place, non-manual (VIIa) in fifth place and, lastly, the agricultural population (IVc + VIIb). 


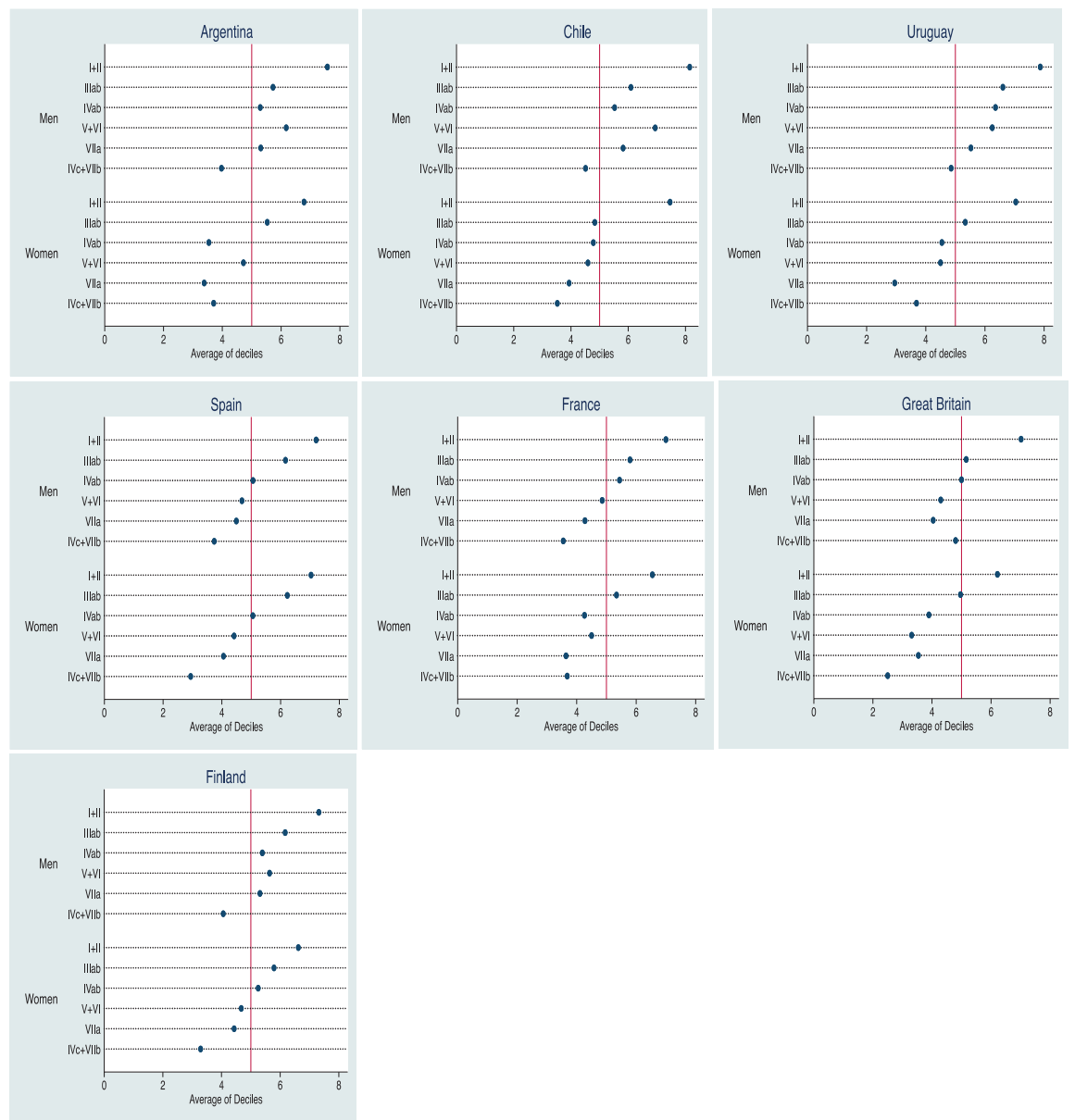

Fig. 6.3 Mean of deciles by family net income and by country. Source: ESS-4 and 5, ENES (Argentina), ENES (Chile), ELPS

Second, in general, classes I + II, IIIab and IVab are above the mean in nearly all the countries. In Spain, Great Britain and France these classes are above the mean for men and women alike and the other countries are below the mean. In turn, in Argentina, Uruguay, Chile and Finland, most of the social classes comprised by men are above the mean. In Argentina, Uruguay and Chile, the mean income of all the social classes of men except IVa + VIIb is above the national mean. This is never observed for women.

Third, although the income is organised in a similar fashion per social class for men and women in the European countries, despite slight differences, it can be observed that the same classes are above or below the mean. 
Fourth, and examining the results in greater detail, the discrepancies according to sex can be observed per class. In the same social class, women are situated in lower deciles values than men. This is further accentuated for women from Latin America. In Chile and Argentina, the order of the mean income per social class is slightly modified as a consequence of the higher score of specialised labourers (V + VI), similar to small employers (IVab). Uruguay, in turn, presents a very similar organisation of class according to income to that of the European countries for men and women.

\subsubsection{Seniority in Employment}

Another fundamental dimension when giving an account of the economic bases and the life opportunities of a social class is the security with which people's existence can be guaranteed. It is important to know how stable the jobs in each social class are. To do so, we study the continued amount of time the members of each social class stay in their job, using seniority measures in the position. In Fig. 6.4, the data obtained for seniority in the job per social class and per sex is shown for the countries selected. ${ }^{8}$

First, large discrepancies cannot be found in the total mean seniority in the job. One of the constants is in agricultural employment which, as could be expected, has higher employment means in almost all countries, except in the case of French women. Likewise, the service class, more in the case of men than women, has an advantageous position. Although it is also certain that the administrative class always has similar years of service, apart from men in Finland. Second, another difference between Europe and Latin America concerns the petite bourgeoisie: while in the European countries, the length of time in jobs in this social class is low, in Latin America they are longstanding and more stable jobs than in Europe.

It is sustained that the longest seniority and therefore the best life opportunities should be in the service (I + II) and routine non-manual (IIIab) classes. But this is not necessarily the case in all the countries. France has very high seniority in jobs for classes I + II, compared to all the other countries, reaching 15 years in jobs for both sexes. Uruguay is close behind, but the rest of the countries present values close to the general mean for seniority in jobs in these classes.

For men in Spain, Great Britain and France, the shortest seniority in jobs is in small business self-employment, clearly less than the general mean of 10 years, and it is important to remember that this is not a large group among men. This is an unprotected and unappealing job for men. Women from the European countries appear to sustain it with more determination: proportionally there are more of them, and they stay longer in the job.

\footnotetext{
${ }^{8}$ In this section, it was not possible to standardise all the data. In the case of Argentina, the available base does not differentiate after five years or more in the company.
} 


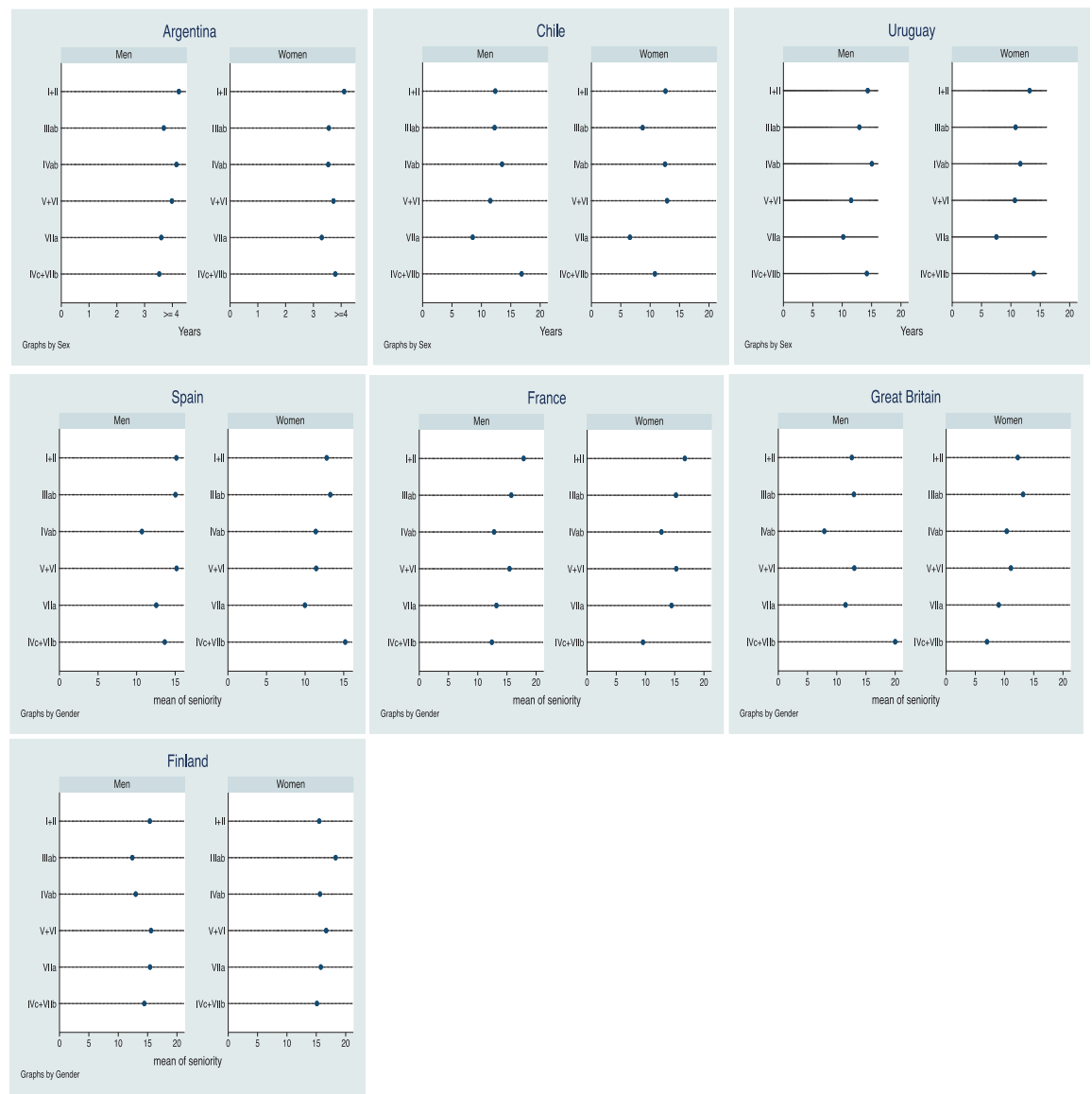

Fig. 6.4 Seniority in employment by sex. Source: ESS-4 and 5, ENES (Argentina), ENES (Chile), ELPS

Apart from Spanish and French women, employment in the agricultural class $(\mathrm{IVc}+\mathrm{VIIb})$ is lasting for men and women from all the countries examined. The sectorial tendency of the EAP that we mentioned in a previous section contrasts with this. Two observations can be made in this respect: for Europeans, the weight of agricultural compensation policies, while Latin Americans are influenced by the effect of production for the exportation of commodities.

In Uruguay and Chile, both sexes, and nearly all the social classes, have a mean seniority that exceeds 10 years, but VIIa (unskilled urban manual workers) always has the least seniority and this can be observed particularly in Spain and Great Britain, but not in France or Finland. 


\subsubsection{Labour Market Sectors and Company Size}

Working in the public or private sector is an important factor in terms of the stability, protection and security conditions of different jobs. It is internationally recognised that the tendency towards poverty decreases substantially when there is at least one public sector employee in the household.

First, we would like to highlight that public sector employment in the European countries is much larger than in Latin American countries. But, once again Spain has an intermediate position in this case. Second, an international trend is corroborated: for 40 years, more women have been employed in the public sector than men. Third, something that can be observed in both men and women is that, uniting classes I + II and IIIab, they reach $50 \%$ of public sector employment, because in all the countries examined they exceed the mean of the sector in terms of the total of EAP. Fourth, and returning to the point that initially highlighted the anticyclical nature of this employment type, here the social force explaining the size of classes I + II and IIIab is corroborated: it is not only a consequence of the productivity of the production factors, or the tax system, or the educational system: there is an effect in itself that is reproduced (Table 6.7).

Company size reflects two interesting aspects for economic bases and life opportunities: the possibility of evolving in the company and therefore of developing a career, and the greater productivity of large companies compared to small ones, promising better salaries and bonuses. Table 6.8 shows the percentage of people who work in companies with less than ten employees.

Table 6.7 Public employment by social class for male and female population

\begin{tabular}{|c|c|c|c|c|c|c|c|}
\hline & FRA & GRB & SPA & FIN & ARG & URY & CHL \\
\hline \multicolumn{8}{|l|}{ Men } \\
\hline $\mathrm{I}+\mathrm{II}$ & 28.76 & 25 & 27.55 & 31.18 & 38.15 & 30.57 & 26.89 \\
\hline IIIab & 27.43 & 43.37 & 29.41 & 42.42 & 26.91 & 24.95 & 31.65 \\
\hline IVab & - & - & - & - & - & - & - \\
\hline$V+V I$ & 17.41 & 13.61 & 14.98 & 17.52 & 18.8 & 21.13 & 14.08 \\
\hline VIIa & 12.68 & 12.66 & 8.71 & 20.49 & 19.84 & 13.64 & 10.81 \\
\hline VIIb+IVc & 20.51 & 22.86 & 3.23 & 14.12 & 4.36 & 1.47 & 0.83 \\
\hline Total & 22.11 & 20.27 & 16.32 & 25.12 & 19.75 & 16.57 & 15.51 \\
\hline \multicolumn{8}{|l|}{ Women } \\
\hline $\mathrm{I}+\mathrm{II}$ & 40.55 & 46.15 & 42.19 & 53.96 & 55.82 & 51.26 & 41.24 \\
\hline IIIab & 39.81 & 48.35 & 35.56 & 56.73 & 28.04 & 25.18 & 25.48 \\
\hline IVab & - & - & - & - & - & - & - \\
\hline $\mathrm{V}+\mathrm{VI}$ & 13.79 & 40 & 5.88 & 20 & 24.3 & 26.74 & 11.11 \\
\hline VIIa & 15.36 & 17.71 & 8.56 & 27.88 & 10.84 & 7.92 & 16.91 \\
\hline VIIb+IVc & 16.67 & 0 & 4.08 & 21.28 & 9.68 & 2.15 & 0 \\
\hline Total & 33 & 40.27 & 23.8 & 46.01 & 25.8 & 21.66 & 24.22 \\
\hline
\end{tabular}

Note: Class IVab does not have public employment

Source: ESS-4 and 5, ENES (Argentina), ENES (Chile), ELPS 
Table 6.8 Proportion of employees in companies of less than 10 employees by country by social class and sex

\begin{tabular}{|c|c|c|c|c|c|c|c|}
\hline & FRA & GRB & SPA & FIN & ARG & URY & CHL \\
\hline \multicolumn{8}{|l|}{ Men } \\
\hline $\mathrm{I}+\mathrm{II}$ & 14.69 & 16.01 & 23.69 & 19.86 & 32.24 & 29.94 & 23.17 \\
\hline IIIab & 11.4 & 8.43 & 27.87 & 20 & 43.65 & 28.11 & 48.65 \\
\hline IVab & 70.13 & 49.09 & 80.23 & 66.02 & 94.74 & 92.32 & 96.7 \\
\hline $\mathrm{V}+\mathrm{VI}$ & 18.91 & 18.67 & 36.84 & 32.78 & 56.9 & 35.42 & 27.41 \\
\hline VIIa & 44.24 & 37.2 & 50.31 & 45.64 & 53.3 & 42.25 & 34.84 \\
\hline $\mathrm{VIIb}+\mathrm{IVc}$ & 65.85 & 77.14 & 67.78 & 82.76 & 66.79 & 73.6 & 57.78 \\
\hline Total & 27.59 & 27.17 & 44.98 & 35.46 & 56.68 & 45.63 & 48.28 \\
\hline \multicolumn{8}{|l|}{ Women } \\
\hline $\mathrm{I}+\mathrm{II}$ & 21.35 & 16.31 & 30.71 & 18.78 & 30.94 & 25.44 & 21.28 \\
\hline IIIab & 22.12 & 11.84 & 34.72 & 22.94 & 54.01 & 34.58 & 54.46 \\
\hline IVab & 47.37 & 29.37 & 61.34 & 38.06 & 96.3 & 94.97 & 98.44 \\
\hline $\mathrm{V}+\mathrm{VI}$ & 46.67 & 40.74 & 51.43 & 30 & 63.59 & 39.25 & 53.65 \\
\hline VIIa & 44.15 & 40.07 & 60.32 & 48.51 & 82.22 & 70.68 & 77.42 \\
\hline $\mathrm{VIIb}+\mathrm{IVc}$ & 60 & 75 & 45.1 & 81.63 & 52.54 & 76.14 & 41.67 \\
\hline Total & 31.58 & 22.74 & 48.72 & 31.66 & 63.24 & 52.5 & 62.65 \\
\hline
\end{tabular}

Note: Class IVab does not have public employment

Source: ESS-4 and 5, ENES (Argentina), ENES (Chile), ELPS

First, the data show that most women and men in Latin America work in small companies of up to 10 employees. On the contrary, in Europe, apart from Spain which stands at approximately 50\% in each sex, the majority of members of any social class work in a company of 10 or more employees. Second in the service class, large companies also prevail. Third, most of the members of the IVab class are self-employed. In Europe, men and women from this social class work preferably in small companies. In turn, in the countries from Latin America, both men and women work exclusively in small companies. Fourth, classes I + II in Europe are concentrated in jobs in large companies at a slightly greater proportion than their counterparts in Latin America. Fifth, class IIIab in Europe prevails in large companies, with the proportion of men being slightly higher than that of women, while in Latin America, the distribution is approximately half and half. Sixth, skilled manual work, represented by classes V + VI, for men and women in Europe, is concentrated in large companies, but in Latin America, half are in companies of 10 employees or less. Unskilled work does not include large companies. On both continents and in both sexes, class VIIa is a large social group that participates very little in the productivity and the other benefits of large companies.

\subsubsection{Education}

One of the recurring questions about educational expansion on a global level is whether this growth has effectively redistributed social, educational and economic opportunities. A position that is consistent with the Treiman Constant would clearly 
deny that this is possible, because the results would always produce the same class or status inequality. It could be worse, since the perspective of the persistent inequalities would indicate that the opportunities were unequally distributed, and the redistributive effect of education would slip away between the borders of classes and welfare (Boudon 1983; Shavit and Blossfeld 1993). We can observe the current situation as an indicative result (Fig. 6.5).

The expected effect of education in the selected countries is not necessarily homogeneous, although regularities and differences can be observed. First, it is important to remember that, after the Second World War, apart from Spain, the selected countries improved the national educational systems substantially with large investments, alongside a systematic widening of the access to primary and secondary education.

For comparative purposes, all the educational levels of each country were codified in the UNESCO ISCED categories. Although we know the difficulty that this means, the benefit of making the comparison outweighs the difficulty. In this case we use ISCED with four categories: completed primary education (Level 0-2), completed secondary education (Level 3), graduated from secondary education or any non-third-level post-secondary education (Level 4) and entered university or any third-level education, even if they did not complete it (Level 5 and more).

As can be observed, access to university has gained strength in Latin America, but it has mainly been accessed by the classes I + II. It is notable that education up to the end of primary is the most frequent educational achievement of classes IVab, V + VI, VIIa and IVc + VIIb in both sexes for the three Latin American countries. In Europe, the situation is no different. Differences can be observed in Spain and Finland, where women from class I + II have accessed higher education en masse. In Great Britain and France this is slightly different and on a lower scale. Men in all cases are behind women in access to university in this class. Low education prevails for men and women in rural occupations, but, as we have already seen, there are not many women in this occupation; the majority are men in the rural environment. The reach of secondary education, considering the legal requirements for many jobs in Europe-not so much in Latin America-is fundamental and stable for men and women. For classes IVab to VIIa, advancing to said level is predominant. The next level, which is pre-university and higher vocational training, is more moderate in Europe. Here a problem of category treatment can arise. In Latin America, a lot of people finish secondary education and obtain their diploma and do not continue to higher education unless it is free (except in Chile). In Europe the decisions appear to have been made earlier, and those who access one level complete it and follow on to the next one, unless the apprenticeship system is in force and higher education is fee-paying, like in Great Britain. In any case, it is important to understand that in Europe the segmentation of the labour market and its educational correlate is much more defined than in Latin America. 

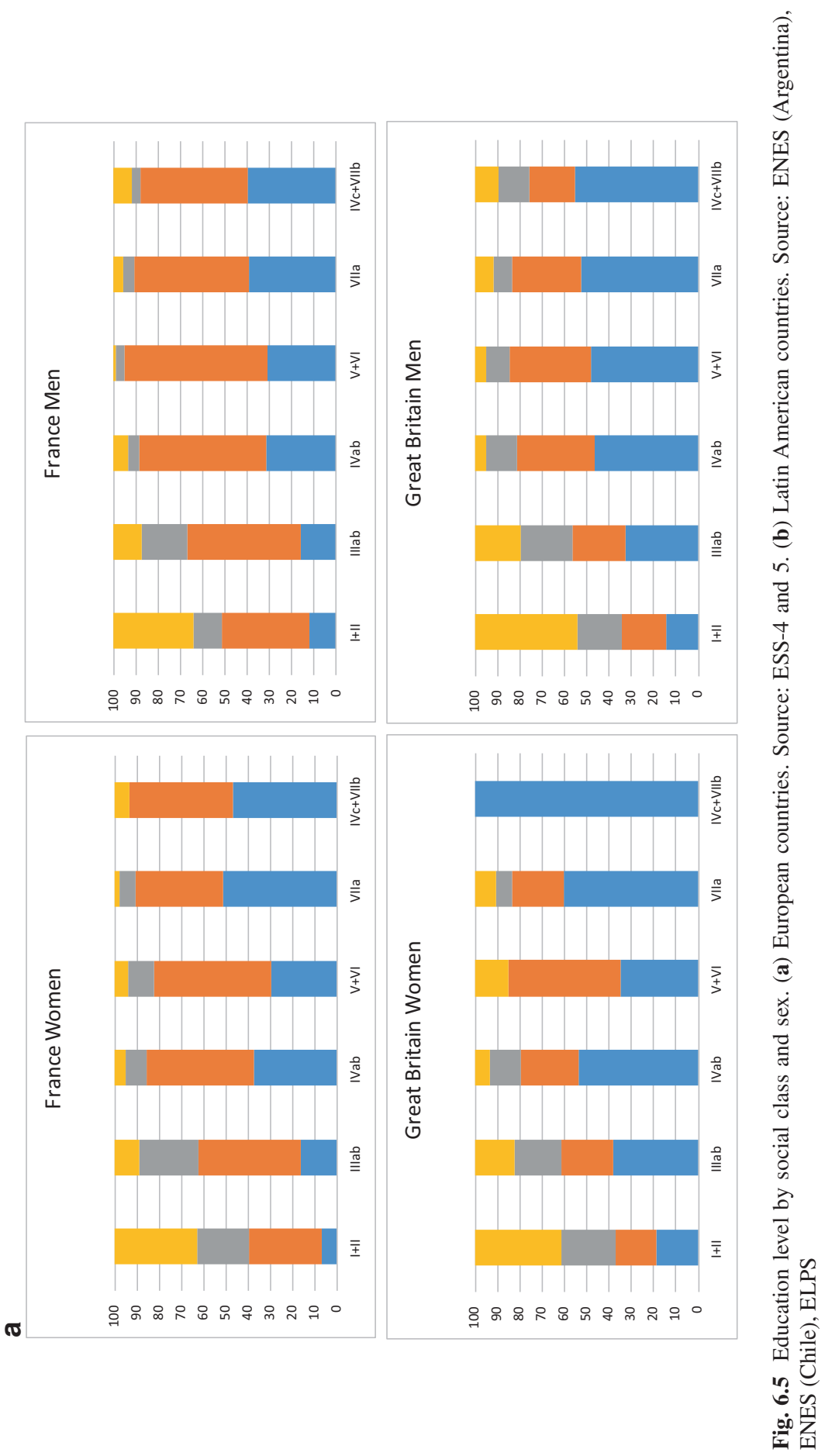


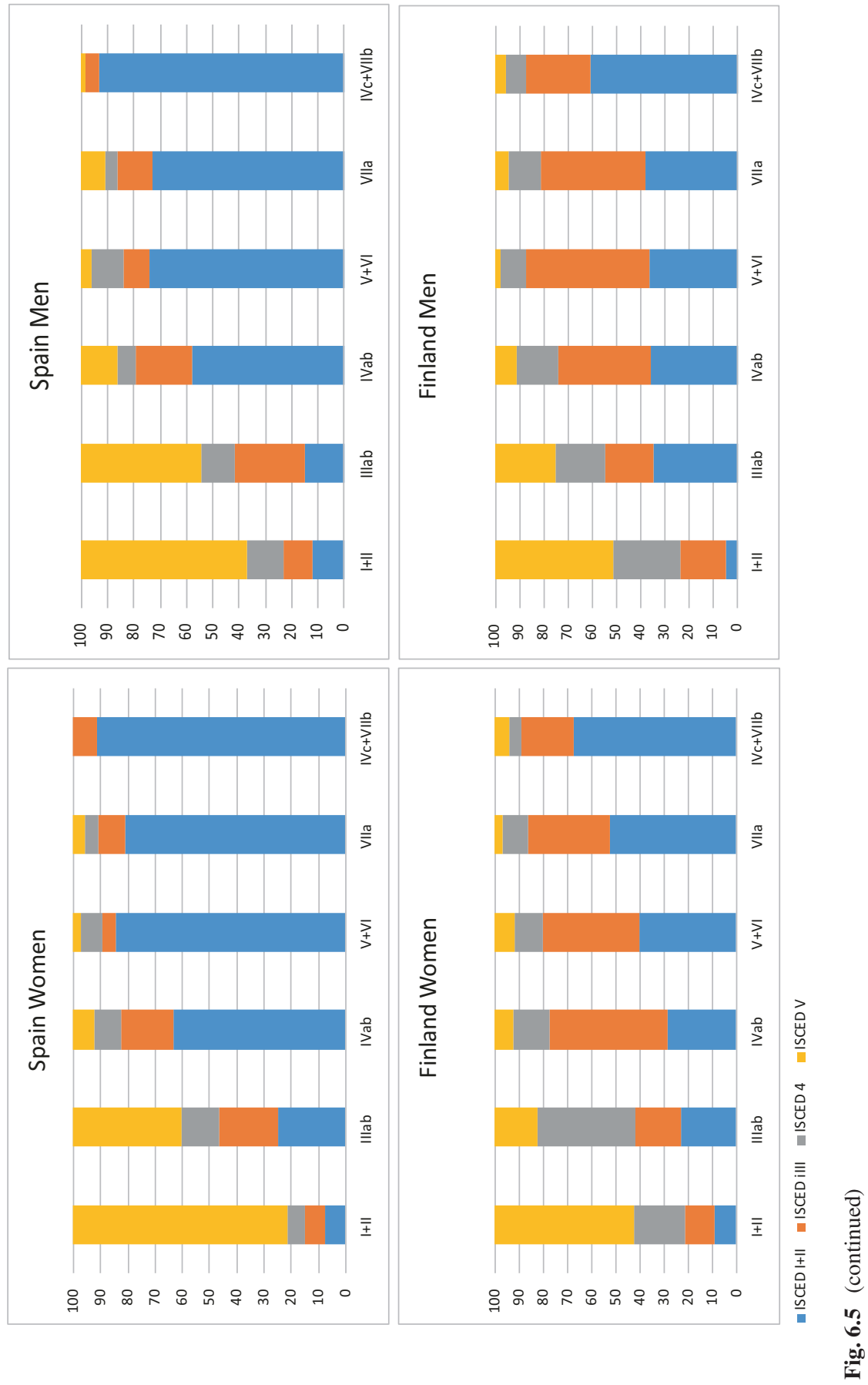




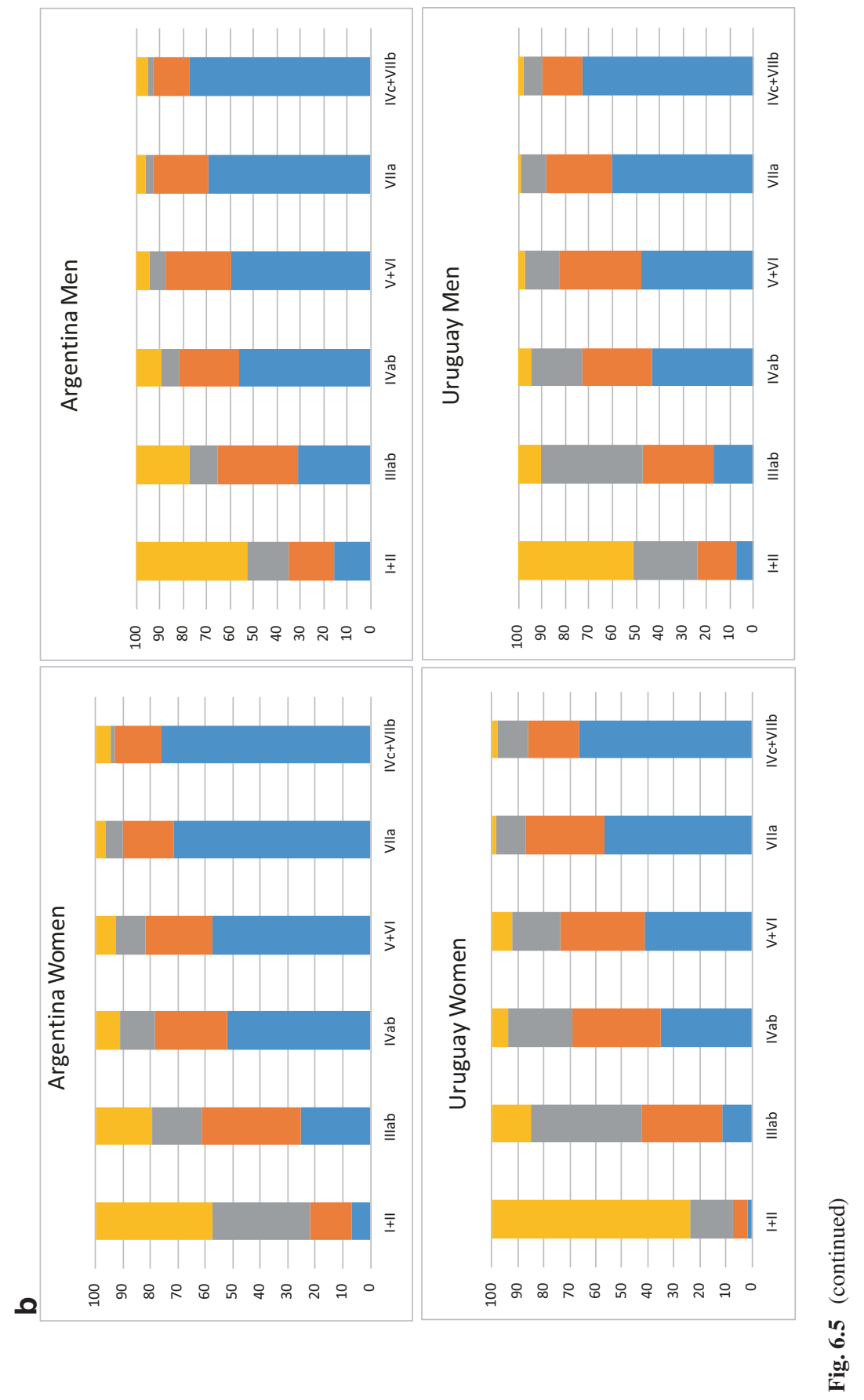



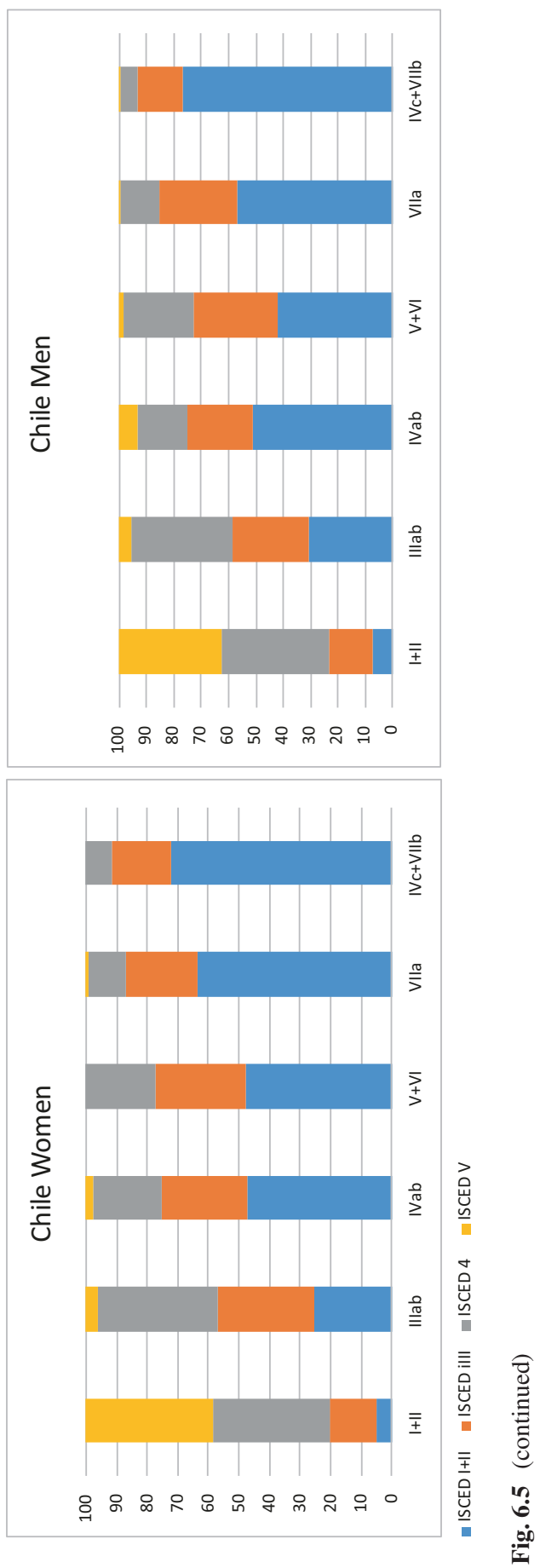
Table 6.9 Proportion of people who claim to have economic problems, by social class and sex

\begin{tabular}{|c|c|c|c|c|c|c|c|c|}
\hline & FRA & GRB & SPA & SPA & FIN & ARG & URY & CHL \\
\hline \multicolumn{9}{|l|}{ Men } \\
\hline $\mathrm{I}+\mathrm{II}$ & 7.87 & 2.2 & 6.72 & 6.72 & 8.78 & 13.21 & 9.26 & 10.55 \\
\hline IIIab & 17.58 & 14.58 & 13.24 & 13.24 & 5.13 & 17.59 & 9.45 & 14.09 \\
\hline IVab & 17.95 & 8.99 & 14.68 & 14.68 & 3.28 & 16.36 & 16.42 & 27.52 \\
\hline $\mathrm{V}+\mathrm{VI}$ & 21.59 & 1.72 & 23.29 & 23.29 & 4.48 & 19.44 & 9.36 & 22.11 \\
\hline VIIa & 22.22 & 9.85 & 18.94 & 18.94 & 6.33 & 15.79 & 18.82 & 21.28 \\
\hline $\mathrm{IV} c+$ VIIb & 30.00 & 0 & 20.95 & 20.95 & 10.81 & 38.1 & 16.57 & 32.09 \\
\hline Total & 15.5 & 6.02 & 15.15 & 15.15 & 6.73 & 17.25 & 12.69 & 20.14 \\
\hline \multicolumn{9}{|l|}{ Women } \\
\hline $\mathrm{I}+\mathrm{II}$ & 10.24 & 4.18 & 8.47 & 8.47 & 3.47 & 13.48 & 12.62 & 12.39 \\
\hline IIIab & 24.47 & 12.78 & 13.22 & 13.22 & 4.62 & 17.39 & 17.78 & 15.22 \\
\hline IVab & 15.38 & 5.71 & 11.48 & 11.48 & 10.81 & 20.34 & 15.22 & 18.69 \\
\hline $\mathrm{V}+\mathrm{VI}$ & 20 & 0 & 25 & 25 & 0 & 33.33 & 14.85 & 26.32 \\
\hline VIIa & 26.56 & 14 & 32.71 & 32.71 & 11.36 & 32 & 25.16 & 25 \\
\hline IVc + VIIb & 25 & 0 & 11.54 & 11.54 & 5.56 & 0 & 20.59 & 40.91 \\
\hline Total & 19.31 & 8.22 & 16.49 & 16.49 & 5.24 & 18.79 & 18.3 & 22.01 \\
\hline
\end{tabular}

Source: EWCS (2015) and Barómetro de las Américas (2010)

\subsubsection{Subjective Perception of Income}

In this section, we show the results obtained regarding the subjective perception of income per country and sex. Table 6.9 shows the percentage of people indicating some or great difficulty making ends meet.

Spain and the Latin American countries have greater insufficiencies than the other countries, both for men and women. However, on this occasion, France joins this block. Almost $20 \%$ of French women consider that their salaries are not sufficient. This value is higher than in Chile and Uruguay. In general, the differences with Finland and Great Britain are, in this case, very marked. According to social class, it is people working in the agricultural sector and labourers, skilled and unskilled, who state that they have more problems, as expected.

\subsection{Validation of Social Classes Through Latent Class Analysis}

On a general level, we have examined the distribution of classes in the EGP framework, observing convergences and divergences. Next, through a set of variables, we have highlighted the economic, social and educational aspects that bring content and substance to the EGP framework. Now we will use a latent class analysis to validate the number of social classes as a way of recognising class borders. 
First, we present the results for the European countries. Subsequently, these findings and its internal traits will be compared with those obtained in Latin America. The latent class analysis is a classifying technique that serves to find, through the estimation of conditioned probabilities, underlying groups in a set of data (Magidson and Vermunt 2004). This is done through the construction of unobserved categorical latent variables. Likewise, this analysis contains objective criteria that guide the determination of the number of groups, namely, in our case, the different social classes (Kaufman and Rousseeuw 1990). Thus, we can estimate parameters that provide us with information about which is the most correct number of groups. Specifically, as we have pointed out in the hypotheses, our prediction stands at approximately six social classes according to the EGP framework: directors and professionals, routine non-manual jobs, petite bourgeoisie, skilled and unskilled labourers and agricultural workers.

The mathematical notation of the latent class analysis is as follows (Monroy et al. 2009). With $\pi$ being the probability, $x_{t}$ the latent variable with $t$ categories and with $\mathrm{T}$ being the total number of cases of the latent variable, then, $\pi\left(x_{t}\right)$ is the probability that a randomly selected individual will belong to the latent class $t(t=1$, $2, \ldots, T)$ and $\pi\left(y_{i} \mid x_{t}\right)$ is the probability of an individual having value $i$ in the variable $y$ considering their belonging to class $t$ in variable $x$.

Consequently, $\pi\left(\begin{array}{lll}y_{1} & y_{2} y_{3} \ldots & y_{i} \mid x_{t}\end{array}\right)$ is the joint probability of a series of response values considering the belonging to class $t$ in variable $x_{i}$.

Formally, the latent class analysis is expressed in the following way.

$$
\pi(Y i \mid y)=\sum_{T}^{t=1} \pi\left(x_{i}=t\right) \prod_{J}^{j=1} \pi\left(Y_{i j}=y_{i j} \mid X_{i}=t\right)
$$

Where $Y$ is the declared variable for case $i, Y_{i j}$ the declared variable for case $i$ in variable $j$, with $J$ number of variables in the model and $X_{i}$ latent variable $t$ which indicates a particular latent class with $T$ numbers of latent classes.

The statistical adjustments used in the latent class model are the Bayesian Information Criterion (BIC) and the Akaike Information Criterion (AIC), whose expressions are as follows:

$$
\begin{gathered}
\mathrm{BIC}=2(\log ) L+q(\log ) N \\
\mathrm{AIC}=2(\log ) L+2 q
\end{gathered}
$$

In which $q$ is the number of parameters of the model and $N$ is the total number of units. Those models presenting a lower BIC and AIC will obtain a better statistical adjustment (Table 6.10). A lower BIC means the best option when choosing a specific number of groups. As an example, if in Spain the lowest BIC reaches three groups, this means that they do not need to be further reduced or increased to give an account of the majority of their variation in terms of the variables studied, namely, educational level, employment sector, sex, unemployment, seniority and company size. 
Table 6.10 Fit statistic for the different classes by country

\begin{tabular}{l|l|l|l|l|l|l|l}
\hline & SPA & FRA & FIN & GRB & ARG & URY & CHL \\
\hline 1 class & 47,750 & 47,639 & 49,222 & 52,316 & 90,850 & 68,158 & 24,181 \\
\hline 2 classes & 46,853 & 47,084 & 48,461 & 51,337 & 87,055 & 65,420 & 23,187 \\
\hline 3 classes & $\mathbf{4 6 , 6 7 9}$ & $\mathbf{4 6 , 8 2 3}$ & $\mathbf{4 8 , 3 3 5}$ & $\mathbf{5 1 , 0 6 8}$ & 86,237 & 64,481 & 22,923 \\
\hline 4 classes & 46,721 & 46,813 & 48,336 & 51,109 & 86,089 & 64,310 & $\mathbf{2 2 , 9 0 3}$ \\
\hline 5 classes & 46,761 & 46,809 & 48,374 & - & 86,030 & 64,209 & 22,940 \\
\hline 6 classes & - & - & - & - & $\mathbf{8 6 , 0 1 8}$ & $\mathbf{6 4 , 1 8 4}$ & - \\
\hline 7 classes & - & - & - & - & 86,019 & 64,249 & - \\
\hline
\end{tabular}

Source: EW, ENES (Argentina), ENES (Chile), ELPS

Bold values indicate the best score (indicated by the lowest BIC in each country)

The best group (indicated by the lowest BIC in each country) is three classes for the European countries, six classes for Argentina and Uruguay, and four for Chile. In Europe, the first of these groups is made up of the substratum with best employment conditions. Its size varies according to the country. In Spain, it reaches $17 \%$ of the entire sample and in France 18\%. On the contrary, for Finland and Great Britain, it reaches $34 \%$ and $33 \%$ respectively. These groups mainly represent managers and professionals of large companies, many of them employed in the public sector, with income above the mean, seniority in their jobs and with low unemployment. They are mainly men, but women are also widely represented.

The second of the classes is very varied, both in size and composition. In the case of Spain (31\%) and Finland (34\%), it is made up of members of the service and routine non-manual classes. In addition to these groups, in Great Britain this set consists of vast sectors of small employers. In France, skilled industrial workers would have to be added, as well as the petite bourgeoisie. Contrary to the members of the first cluster, they work in the private sector, many in small companies and apart from in Finland, their salaries are below the mean salary. A difference compared to the first group is that the number of women is higher, and their education exceeds, in all cases, the basic levels. The third group is made up of manual workers, skilled and unskilled, agricultural and non-agricultural. For Spain and Great Britain, it also includes a fraction of the petite bourgeoisie. Its size is approximately $30 \%$ apart from Spain where it reaches $51 \%$. The working conditions are characterised for being worse than the other two resulting groups.

For Latin America, the case of Chile is different from the case of Argentina and Uruguay. In this country, only four classes were obtained. A first cluster is made up of an analogous group to the first one obtained in the European countries, but smaller (7\%). A second group (24\%) corresponds to members of the service class, but from the public sector, in addition to skilled manual workers. The third group (17\%) is made up of the petite bourgeoisie and the agricultural sectors with income below the mean, but with long seniority in the job. The fourth class that encompasses most of the population (52\%) has the worst working conditions and is made up of both routine non-manual workers and unskilled manual workers. This class also consists principally of women and presents a higher number of unemployed people. 
Argentina and Uruguay have six latent classes. In Argentina, the first of these $(15 \%)$ is made up of members of the service class, and to a large extent, women. The second $(32 \%)$ by skilled workers and workers in the agricultural sector of any type, who are above the mean wage and have long seniority in their jobs. The third group, which is the majority (36\%), comprises the petite bourgeoisie and unskilled manual workers. In this cluster, the proportion of men is very high. They work for small companies from the low-income private sector but have long seniority in their jobs. The fourth group represents $7 \%$ of the sample; it has a majority of men working in small companies, with a low income and good education, with routine non-manual and agricultural sector classes. The fifth group is made up of $7 \%$ of the sample, and comprises the routine non-manual class, and unskilled manual workers, with low income, education and little seniority, but it has high levels of unemployed people. ${ }^{9}$ Lastly, a scarce $2 \%$ make up the sixth group, composed of women in unskilled jobs, but in large companies from the public sector with an education level above the basic education.

Lastly, the case of Uruguay is also made up of six latent classes. The first of these corresponds to managerial and professional women and the second to managerial, professional men and workers from the routine non-manual class. Apart from sex, the main difference lies in the size: $10 \%$ in the case of men and $23 \%$ in the case of women. These two groups have the same characteristics as the first of the latent classes in Europe and Latin America. There is also a group (14\%) composed of average strata: petite bourgeoisie and skilled workers. The main difference with regard to the first two groups stems from the private nature of many of these businesses and their shorter seniority. The fourth cluster (10\%) is made up of skilled and unskilled workers. Unlike the previous group, despite working in large companies, their income is below the mean. The next latent class is composed of a scarce $8 \%$ and is made up of small urban employers and employers in the agricultural sector and their workers. Lastly, the main group (34\%) is composed of part of the routine non-manual class, part of the urban petite bourgeoisie and part of the unskilled manual workers. This cluster has a higher number of unemployed people, persons who work for small companies and short seniority; it also has a high number of women.

\subsection{Conclusions}

According to the Treiman Constant, which states that employment follows the same order in all societies, in this chapter we seek to verify this idea and in turn analyse how similar the social classes in Europe and Latin America are. To do so, we used a diverse set of countries that represent the welfare regimes on both continents. Not

\footnotetext{
${ }^{9}$ People who had a previous job and could be analysed by describing the characteristics of their previous jobs.
} 
only are there distinctions between Europe and Latin America; within each continent notable differences could also be observed. To give an account of the life opportunities of each social class, we have chosen the following variables: deciles, educational levels, type of workday, type of contract and seniority.

The first conclusion to be drawn is as follows: despite different historical trajectories, distinct welfare regimes and various development levels, the structure organising social classes is very similar. The classification used, which is the one most circulated in social stratification studies, provides a very relevant view of the structure of classes in different countries. However, there are differences. Advanced economies achieve that a large proportion of the population are in the service class. Since the living conditions of this class are much higher than for the rest of the social classes, a large section of the population of these societies has high standards of living. By way of example, while $14 \%$ of Uruguayan men belong to the service class, this same figure reaches $40 \%$ in the Finnish population. Likewise, it is important to note that there is a larger agricultural population in the countries in Latin America while two countries that underwent industrialisation later such as Finland and Spain still have a large agricultural sector. Likewise, it is important to point out that it has also been demonstrated that segregation according to gender is generalised. The class structure in all the countries selected differs greatly according to whether they are men or women, even for those in nations with a much better equipped welfare state, such as Finland.

The second conclusion refers to the education level attained by the different social classes. In Europe, educational growth has been more intense and, perhaps for these very circumstances, has reached a higher number of social classes. This educational growth has also particularly reached women in Latin America, although in some countries they are behind their European counterparts.

The third conclusion stems from the employment conditions of the different social classes. Here there are not many points of convergence between Europe and Latin America. The working conditions of Latin American countries have more disadvantages than those of their European counterparts, including those from the south of Europe. As we go from more industrialised to less industrialised economies, fewer social classes reach adequate work conditions and more decent life opportunities.

On the other hand, the fact that the statistical indicators of the latent class analysis reflect different amounts of classes also indicates different levels of inequality. Thus, we can observe that Europe's citizens are integrated in three large groups, while Latin America has greater stratification between its classes.

Lastly, it is important to point out that this study provides the opportunity to compare social structures that have rarely been compared. The previous theoretical content has not only enabled us to begin our research, but it enables us to test different theoretical ideas. In those societies with a market economy and a nuclear family, the role of the State does not appear to modify the social class structure. However, according to the level of development taking place, a higher number of classes have better social opportunities. 
Acknowledgments We acknowledge the support of CONICYT/FONDAP/15130009, FONDECYT 1190436, CSIC/UdelaR (Universidad de la República) and the microdata granted by LPS/BPS, ENES/MINCYT, ELPS/CHILE).

\section{Appendix: Main Characteristics of the Data Sources}

\begin{tabular}{l|l|l|l}
\hline $\begin{array}{l}\text { Latin } \\
\text { America }\end{array}$ & Argentina & Chile & Uruguay \\
\hline Surveys & $\begin{array}{l}\text { ENES/PISAC and } \\
\text { AmericasBarometer (AB) }\end{array}$ & $\begin{array}{l}\text { ENES and } \\
\text { AmericasBarometer (AB) }\end{array}$ & $\begin{array}{l}\text { ELPS and } \\
\text { AmericasBarometer (AB) }\end{array}$ \\
\hline Years & $\begin{array}{l}\text { 2014 and 2010 and 2010 } \\
\text { 2012 and 2010 }\end{array}$ \\
\hline $\begin{array}{l}\text { Geographic } \\
\text { coverage }\end{array}$ & National coverage & National coverage & National coverage \\
\hline $\begin{array}{l}\text { Population } \\
\text { Population in households } \\
\text { across the country } \\
\text { AB: over 18 years }\end{array}$ & $\begin{array}{l}\text { Employed persons } \\
\text { between age 20 and } 64 \\
\text { AB: over 18 years }\end{array}$ & $\begin{array}{l}\text { Individuals over 14 years } \\
\text { old in households across } \\
\text { the country } \\
\text { AB: over 18 yeas }\end{array}$ \\
\hline $\begin{array}{l}\text { Type of } \\
\text { survey }\end{array}$ & Face to face & Face to face & Face to face \\
\hline $\begin{array}{l}\text { Sample size } \\
\text { ANES/PISAC: 27803 }\end{array}$ & $\begin{array}{l}\text { ENES: 2830 } \\
\text { AB: 677 }\end{array}$ & $\begin{array}{l}\text { ELPS: 17043 } \\
\text { AB: 799 }\end{array}$ \\
\hline $\begin{array}{l}\text { Institution or } \\
\text { team in } \\
\text { charge 1st } \\
\text { survey }\end{array}$ & $\begin{array}{l}\text { Min Ciencia y } \\
\text { Tecnología- PISAC } \\
\text { LAPOP }\end{array}$ & $\begin{array}{l}\text { Proyecto Anillo } \\
\text { LAPOP }\end{array}$ & $\begin{array}{l}\text { Banco de Previsión } \\
\text { Social } \\
\text { LAPOP }\end{array}$ \\
\hline $\begin{array}{l}\text { Variables } \\
\text { used for the } \\
\text { construction } \\
\text { of social class }\end{array}$ & $\begin{array}{l}\text { CIUO 88, position, firm } \\
\text { size, supervision } \\
\text { AB: own classification }\end{array}$ & $\begin{array}{l}\text { CIUO 88, position, firm } \\
\text { size, supervision } \\
\text { AB: own classification }\end{array}$ & $\begin{array}{l}\text { CIUO 88, position, firm } \\
\text { size, supervision } \\
\text { AB: own classification }\end{array}$ \\
\hline
\end{tabular}

\begin{tabular}{|c|c|c|c|c|}
\hline Europe & France & Finland & Spain & Great Britain \\
\hline Surveys & $\begin{array}{l}\text { European Social } \\
\text { Survey and } \\
\text { European Working } \\
\text { Conditions Survey }\end{array}$ & $\begin{array}{l}\text { European Social } \\
\text { Survey and } \\
\text { European Working } \\
\text { Conditions Survey }\end{array}$ & $\begin{array}{l}\text { European Social } \\
\text { Survey and } \\
\text { European Working } \\
\text { Conditions Survey }\end{array}$ & $\begin{array}{l}\text { European Social } \\
\text { Survey and } \\
\text { European Working } \\
\text { Conditions Survey }\end{array}$ \\
\hline Years & $\begin{array}{l}\text { ESS 2008, } 2010 \text { and } \\
2015 \\
\text { EWCS } 2010\end{array}$ & $\begin{array}{l}\text { ESS 2008, } 2010 \\
\text { and } 2015 \\
\text { EWCS } 2010\end{array}$ & $\begin{array}{l}\text { ESS 2008, } 2010 \\
\text { and } 2015 \\
\text { EWCS } 2010\end{array}$ & $\begin{array}{l}\text { ESS 2008, } 2010 \\
\text { and } 2015 \\
\text { EWCS } 2010\end{array}$ \\
\hline Population & $\begin{array}{l}\text { All persons aged } 15 \\
\text { and over resident } \\
\text { within private } \\
\text { households. EWCS: } \\
\text { over } 18 \text { years }\end{array}$ & $\begin{array}{l}\text { All persons aged } \\
15 \text { and over } \\
\text { resident within } \\
\text { private households. } \\
\text { EWCS: over } 18 \\
\text { years }\end{array}$ & $\begin{array}{l}\text { All persons aged } \\
15 \text { and over } \\
\text { resident within } \\
\text { private households. } \\
\text { EWCS: over } 18 \\
\text { years }\end{array}$ & $\begin{array}{l}\text { All persons aged } \\
15 \text { and over } \\
\text { resident within } \\
\text { private households. } \\
\text { EWCS: over } 18 \\
\text { years }\end{array}$ \\
\hline $\begin{array}{l}\text { Type of } \\
\text { survey }\end{array}$ & Face to Face & Face to Face & Face to Face & Face to Face \\
\hline Sample size & \begin{tabular}{|l|} 
ESS 3451 \\
EWCS 1431
\end{tabular} & $\begin{array}{l}\text { ESS } 3890 \\
\text { EWCS } 938\end{array}$ & \begin{tabular}{|l|} 
ESS 3702 \\
EWCS 3130
\end{tabular} & $\begin{array}{l}\text { ESS } 4523 \\
\text { EWCS } 1516\end{array}$ \\
\hline
\end{tabular}




\begin{tabular}{l|l|l|l|l}
\hline Europe & France & Finland & Spain & Great Britain \\
\hline $\begin{array}{l}\text { Institution } \\
\text { or team in } \\
\text { charge }\end{array}$ & $\begin{array}{l}\text { European } \\
\text { Commission, the } \\
\text { European Science } \\
\text { Foundation and } \\
\text { national funding } \\
\text { councils, } \\
\text { Eurofound }\end{array}$ & $\begin{array}{l}\text { European } \\
\text { Commission, the } \\
\text { European Science } \\
\text { Foundation and } \\
\text { national funding } \\
\text { councils, } \\
\text { Eurofound }\end{array}$ & $\begin{array}{l}\text { European } \\
\text { Commission, the } \\
\text { European Science } \\
\text { Foundation and } \\
\text { national funding } \\
\text { councils, } \\
\text { Eurofound }\end{array}$ & $\begin{array}{l}\text { European } \\
\text { Commission, the } \\
\text { European Science } \\
\text { Foundation and } \\
\text { national funding } \\
\text { councils, } \\
\text { Eurofound }\end{array}$ \\
\hline $\begin{array}{l}\text { Variables } \\
\text { used for the } \\
\text { construction } \\
\begin{array}{l}\text { of social } \\
\text { class }\end{array}\end{array}$ & ISCO-88 & ISCO-88 & ISCO-88 & ISCO-88 \\
\hline
\end{tabular}

\section{References}

Barómetro de las Américas (2010). Latin American Public Opinion Project. Vanderbilt University. https://www.vanderbilt.edu/lapop/ab2010.php

Barro, R., \& Lee, J. W. (2013). A new data set of educational attainment in the world, 1950-2010. Journal of Development Economics, 104, 184-198. https://doi.org/10.3386/w15902.

Bolt, J., Inklaar, R., de Jong, H. \& van Zanden, J.L. (2018). Rebasing 'Maddison': New income comparisons and the shape of long-run economic development. Working Paper, 10. Retrieved from Maddison Project website: www.ggdc.net/maddison

Boudon, R. (1983). La desigualdad de oportunidades. Barcelona: Laia.

Cardoso, F. H., \& Faletto, E. (1969). Dependencia y desarrollo en América Latina. México: Siglo XX.

Castells, M. (1996). The information age: economy, society, and culture (The rise of the network society) (Vol. 1). Oxford: Blackwell.

Chauvel, L. (2006). Le destin des générations. Paris: PUF.

Chena, P. (2009). Heterogeneidad estructural y distribución del ingreso. Una aproximación teórica a esta relación desde diferentes teorías económicas. Paper presented at the 9o Congreso Nacional de Estudios del Trabajo: El trabajo como cuestión central, Asociación Argentina de Especialistas en Estudios del Trabajo (ASET), Buenos Aires, FCEUBA

Crompton, R., \& Mann, M. (Eds.). (1986). Gender and stratification. Cambridge: Polity Press.

Erikson, R., \& Goldthorpe, J. (1992). The constant flux: A study of class mobility in industrial societies. Oxford: Clarendon Press.

Esping-Andersen, G. (1990). The three worlds of welfare capitalism. Princeton: Princeton University.

European Working Conditions Survey (EWCS) 2015.

Filgueira, C. H. \& Geneletti, C. (1981). Estratificación y movilidad ocupacional en América Latina. Cuadernos de la CEPAL n³9. Santiago de Chile: CEPAL.

Friedman, T. (1999). The lexus and the olive tree. New York: Farrar Straus Giroux.

Gerschenkron, A. (1962). Economic backwardness in historical perspective. A book of essays. Cambridge, MA: Belknap Press of Harvard University Press.

Grusky, D. (2001). Social stratification: Class, race and gender in sociological perspective. Boulder: Westview Press.

Hall, P. A., \& Soskice, D. (2001). Varieties of capitalism: The institutional foundations of comparative advantage. Oxford: Oxford University Press. 
Hertel, F. R. (2017). The derivation of the IPICS class scheme. In F. R. Hertel (Ed.), Social mobility in the 20th century (pp. 91-117). Wiesbaden: Springer VS.

Hout, M., \& Di Prete, T. A. (2006). What we have learned. RC28's contributions to knowledge about social stratification. Research in Social Stratification and Mobility, 24, 1-20. https://doi. org/10.1016/j.rssm.2005.10.001.

Inglehart, R. \& Baker,W.E. (2000). Modernization, cultural change, and the persistence of traditional values. American Sociological Review, 65(1), 19-51. Doi: https://doi.org/10.2307/2657288.

Inkeles, A., \& Rossi, P. H. (1956). National comparisons of occupational prestige. American Journal of Sociology, 61, 329-339. https://doi.org/10.1086/221764.

Ishida, H. (2008). Social stratification and social mobility in late-industrializing countries. The 2005 SSM Research Series 14. Retrieved from http://srdq.hus.osaka-u.ac.jp/PDF/2005\%20 SSM\%20Report\%20Vol.14.pdf

Kaufman, L., \& Rousseeuw, P. (1990). Finding groups in data: An introduction to cluster analysis. New York: Wiley.

Korpi, W. (1983). The democratic class struggle. Boston: Routledge \& Kegan Paul.

Maddison, A. (2006). The world economy, Vol. 1: A millennial perspective and Vol. 2: Historical statistics. Paris: OECD.

Magidson, J., \& Vermunt, J. K. (2004). Latent class models. In D. Kaplan (Ed.), The Sage handbook of quantitative methodology for the social sciences (pp. 175-198). Thousands Oakes: Sage.

Maloutas, T. (2009). Urban outcasts: A contextualized outlook on advanced marginality. International Journal of Urban and Regional Research, 33(3), 828-834. https://doi. org/10.1111/j.1468-2427.2009.00925.x.

Marqués Perales, I., \& Chávez Molina, E. (2019). Relevancia de la heterogeneidad socioeconómica: Estudio comparativo entre América Latina y Europa basado en la adaptación del Esquema EGP. Papers, 104(2), 225-245. https://doi.org/10.5565/rev/papers.2575.

Monroy, L., Vidal, R., \& Saade, A. (2009). Análisis de clases latentes: una técnica para detectar heterogeneidad en poblaciones (Cuaderno técnico 2). México: Centro Nacional de Evaluación para la Educación Superior.

Moreno, L. (2006). The model of social protection in Southern Europe: enduring characteristics? Revue française des affaires sociales, 1(5), 73-95. https://doi.org/10.3917/rfas.en605.0073.

Penissat, É., \& Siblot, Y. (2017). Des classes sociales européennes ? Actes de la recherche en sciences sociales, 219(4), 4-11. https://doi.org/10.3917/arss.219.0004.

Pinto, A. (1969). Diagnóstico, estructura y esquemas de desarrollo en América Latina. Escuela Latinoamericana de Sociología-FLACSO.

Portes, A., \& Hoffman, K. (2003). Latin American class structures: Their composition and change during the Neoliberal Era. Latin American Research Review, 38, 41-82. https://doi. org/10.1080/14616690701336518.

Prebisch, R. (1949). El Desarrollo Económico de América Latina y su Principales Problemas. New York: United Nations.

Rose, D., \& Harrison, E. (2007). The European socio-economic classification: A new social class schema for comparative European research. European Societies, 9(3), 459-490. https://doi. org/10.1080/14616690701336518.

Shavit, Y., \& Blossfeld, H. P. (1993). Persisting barriers: Changes in educational opportunities in thirteen countries. In Y. Shavit \& H. P. Blossfeld (Eds.), Persistent inequality: Changing educational attainment in thirteen countries. Westview: Colorado.

Solis, P., \& Boado, M. (2016). Y sin embargo se mueve... Estratificación social y movilidad intergeneracional de clase en América Latina. México: Centro de Estudios Espinosa Yglesias, El Colegio de México.

Solís, P., Chávez Molina, E., \& Cobos, D. (2019). Class structure, labor market heterogeneity, and living conditions in Latin America. Latin American Research Review, 54(4), 854-876. https:// doi.org/10.25222/larr.442.

Torrado, S. (1998). Familia y diferenciación social. Buenos Aires: Eudeba. 
Treiman, D. J. (1970). Industrialization and social stratification. Sociological Inquiry, 40(2), 207-234. https://doi.org/10.1111/j.1475-682X.1970.tb01009.x.

Treiman, D. J. (1975). Problems of concept and measurement in the comparative study of occupational mobility. Social Science Research, 4(3), 183-230. https://doi. org/10.1016/0049-089X(75)90012-5.

Treiman, D. J. (1977). Occupational prestige in comparative perspective. New York: Academic Press.

Wallerstein, I. (1974). The modern World System I: Capitalist agriculture and the origins of the European world-economy in the sixteenth century. New York: Academic Press.

Wallerstein, I. (2000). The essential Wallerstein. New York: The New York Press.

World Bank. (2015). Annual report. New York: World Bank.

Wright, E. O. (1997). Class counts: Comparative studies in class analysis. Cambridge, NY: Cambridge University Press.

Open Access This chapter is licensed under the terms of the Creative Commons Attribution 4.0 International License (http://creativecommons.org/licenses/by/4.0/), which permits use, sharing, adaptation, distribution and reproduction in any medium or format, as long as you give appropriate credit to the original author(s) and the source, provide a link to the Creative Commons licence and indicate if changes were made.

The images or other third party material in this chapter are included in the chapter's Creative Commons licence, unless indicated otherwise in a credit line to the material. If material is not included in the chapter's Creative Commons licence and your intended use is not permitted by statutory regulation or exceeds the permitted use, you will need to obtain permission directly from the copyright holder. 